Bulletin of Pharmaceutical Sciences
Assiut University
Website: http://bpsa.journals.ekb.eg/
e-mail: bullpharm@aun.edu.eg

\title{
IN-VITRO ANTIBACTERIAL ACTIVITY AND CHEMICAL COMPOSITION OF SYRIAN ERICA MANIPULIFLORA ESSENTIAL OIL
}

\author{
Lamis Talal Tlas $^{1 *}$, Isam Chamaa ${ }^{1}$, Jalal Fandi ${ }^{1}$ and Emad Al Haddad ${ }^{2}$ \\ ${ }^{1}$ Department of Pharmacognosy, Faculty of Pharmacy, Damascus University, Damascus, Syria \\ ${ }^{2}$ Department of Pharmaceutical Chemistry and Drug Control, Faculty of Pharmacy, Al Baath \\ University, Homs, Syria
}

\begin{abstract}
In current research, we aimed to investigate the chemical composition of the EO of Erica manipuliflora extracted in two growth periods (before flowering and full flowering periods), to evaluate the differences between the two EOs in antibacterial activity against four pathogenic bacteria (Bacillus subtilis, Staphylococcus aureus, Escherichia coli and Salmonella enteritidis). Results showed the existence of 17 and 23 volatile components in the EOs extracted from E. manipuliflora before flowering and in full flowering periods, respectively. The main components in EO extracted from the plant before flowering period were Germacrene-D, taucadinol, $\beta$-caryophellene, Trans-pinocarveol and $\beta$-pinene; which represented 35.02, 26.36, $14.78,9.25$ and $3.65 \%$, respectively. The EO extracted from the plant collected in full flowering period were $\beta$-citral, $\beta$-pinene, Germacrene-D, tau-cadinol and Trans-pinocarveol, which represented 22.26, $18.50,16.90,11.89$ and 5.58\%, respectively. The EO extracted from E. manipuliflora in the full flowering period was more active than that extracted before flowering period towards the bacterial species mentioned above. The most sensitive bacterium towards E. manipuliflora EOs was Bacillus subtilis, while the most resistant one was Salmonella enteritidis.
\end{abstract}

\section{INTRODUCTION}

Spices and herbs have been used for thousands of centuries by many cultures to enhance the flavor and aroma of foods. Early cultures also recognized the value of using spices and herbs in preserving foods and for their medicinal value. Scientific experiments since the late $19^{\text {th }}$ century have documented the antimicrobial properties of some spices, herbs, and their components ${ }^{1 \& 2}$.

In many countries, folk medicines widely resort to medicinal plants as primary tools to treat many diseases; the study of such traditional practices has uncovered many drugs of importance and is still a cornerstone of modern drug discovery ${ }^{3}$. In the last decades, herbal medicines have received much attention in Western and Eastern countries as sources of biologically active substances, notably for the discovery of antioxidant, antimutagenic, anticarcinogenic and cytotoxicagents ${ }^{4}$.

The Ericaceae, a large cosmopolitan family represented by 4100 species regrouped in 124 genera, notably Arbutus, Calluna and Erica, present the highest diversity under the Mediterranean climates ${ }^{5}$. Medicinal properties have long been recognized for some Ericaceae which led to their inclusion in the list of species that may enter into the composition of herbal medicines ${ }^{6}$. The therapeutic functions of Ericaceae species are generally attributed to their abundant polyphenolic compounds ${ }^{7}$.

The genus Erica L. is a member of the family Ericaceae and more than 800 species naturally grow in the world, mainly in the coastal areas of the Mediterranean Sea ${ }^{8-11}$.

Since ancient times, Erica species have been used as a traditional medicine for the treatment of burns and wounds. The studies 
have been showed that Erica species possess antiulcer ${ }^{12 \& 13}$, antimicrobial ${ }^{14 \& 15}$, antibacterial, cytotoxic $^{16-19}$, and antioxidant ${ }^{20-24}$ activities. It has also been reported that Erica species have polyphenolic, flavonoid, coumarin and triterpenoid, compounds ${ }^{25-32}$.

According to our knowledge, there is no study in the literature on antibacterial activity and chemical composition of essential oil of $E$. manipuliflora growing in Syria. So this study aimed to evaluate the antibacterial activity Erica manipuliflora essential oil extracted from aerial parts of the plant in two different growth periods (before flowering and full flowering periods), against some pathogenic bacteria, namely: Bacillus subtilis, Staphylococcus aureus, Escherichia coli and Salmonella enteritidis by estimating the value of minimum bactericidal concentration (MBC). The second aim was to investigate chemical composition of Erica manipuliflora essential oil, extracted in the two periods, by means of gas chromatography-mass spectometry (GC-MS) technique.

\section{MATERIALS AND METHODS}

\section{Plant materials}

The current study was executed in the National Commission for Biotechnology (NCBT), Damascus, Syria. Erica manipuliflora was collected from Masyaf, Syria (850 m over sea level, Latitude: $34^{\circ}$ 53' 20.47" North, Longitude: $35^{\circ} 53^{\prime} 11.72^{\prime \prime}$ East, climate: cold in winter and moderate in summer) in two growth periods: before flowering and full flowering. The aerial parts of plant were washed with tap water, wiped with clean cloth and dried at room temperature, then used immediately for essential oils extraction.

\section{Extraction of EOs}

The EOs of washed-air dried aerial parts of E. manipuliflora were extracted by hydrodistillation using Clevenger type apparatus. The upper oily layers were separated from the aqueous lower layers by centrifuging (6000 rpm for $20 \mathrm{~min}$.). The oily layers were collected and dried over anhydrous sodium sulphate, and stored in amber air-tight glass vial at $-20^{\circ} \mathrm{C}$ in the absence of light until they were used in antibacterial activity assay, or analyzed for chemical composition ${ }^{3 \& 34}$.
Bacterial strains source, subculture and maintenance

Bacterial strains (Bacillus subtilis, Staphylococcus aureus, Escherichia coli and Salmonella enteritidis) were obtained from the National Commission for Biotechnology (Damascus-Syria). The strains were preserved in a mixture consists of Nutrient Broth: glycerol; 80: $20(\mathrm{~V} / \mathrm{V})$, and stored at $-80^{\circ} \mathrm{C}$. Before antibacterial activity tests, the stored cultures were streaking on Nutrient agar plates and incubation at $37^{\circ} \mathrm{C}$ for $24 \mathrm{hrs}$. Good isolated colonies were selected to prepare bacterial suspensions used for determination of MBC values.

\section{Antibacterial activity assay}

Antibacterial activity assay (expressed as MBC value) was performed according to the method described by Sheeladevi and Ramanathan ${ }^{35}$ with some modifications. Sterile Nutrient broth was distributed aseptically in sterile $2 \mathrm{~mL}$ tubes. Well isolated colonies of each bacterial strain grown on Nutrient agar for $24 \mathrm{hrs}$. were used to prepare cell suspensions in the concentration of $10^{6} \mathrm{cfu} / \mathrm{ml}$. $E$. manipuliflora EOs were used to prepared concentrations of 2, 4, 8, 16 and $32 \mathrm{mg} \cdot \mathrm{ml}^{-1}$ in Nutrient Broth, using Tween $80(0.5 \%$ by volume) as emulsifier. Ten $\mu$ of each bacterial suspension $\left(10^{6} \mathrm{cfu} / \mathrm{ml}\right)$ was inoculated into each tube containing the mixture of essential oil, tween 80 and Nutrient Broth. The tubes were inoculation with $10 \mu \mathrm{l}$ of each bacterial suspension and vortexed, then incubated at $37^{\circ} \mathrm{C}$ for $24 \mathrm{hrs}$. Nutrient Broth plus the emulsifier (tween 80) without the addition of any EOs, was used as positive control. After incubation period passed, $10 \mu \mathrm{l}$ of each tube was transferred into a Petri dish containing Nutrient agar. The inoculated Petri dishes were incubated at $37^{\circ} \mathrm{C}$ for $24 \mathrm{hrs}$. and the presence/absence of growth was recorded (+: growth present; -: growth absent). The lowest EO concentration at which every bacterium did not demonstrate any visible growth on the Petri dish after incubation for $24 \mathrm{hrs}$. at $37^{\circ} \mathrm{C}$ was determined as MBC.

\section{Gas chromatography-mass spectrometry analysis}

The chemical composition of EOs extracted from E. manipuliflora were identified 
by means of gas chromatograph (Agilent 7890A, autosampler Agilent 7683B) equipped with mass spectrometry (Agilent 5975C) using HB-5MS capillary column $(30 \mathrm{~m} \times 0.25 \mathrm{~mm} \times$ $0.25 \mu \mathrm{m})$. GC/MS spectrum was obtained according to the following conditions: carrier gas, Helium at $104 \mathrm{ml} / \mathrm{min}$; split ratio, 1: 100; injection volume, $1 \mu \mathrm{l}$; temperature of injector $250^{\circ} \mathrm{C}$; column oven temperature program as following: $40^{\circ} \mathrm{C}$ for $2 \mathrm{~min}$.; then $40 \rightarrow 70^{\circ} \mathrm{C}$ at $2.5^{\circ} \mathrm{C} / \mathrm{min}$.; $70 \rightarrow 130^{\circ} \mathrm{C}$ at $2^{\circ} \mathrm{C} / \mathrm{min}$. for $2 \mathrm{~min}$; $130 \rightarrow 160^{\circ} \mathrm{C}$ at $2.5^{\circ} \mathrm{C} / \mathrm{min}$; $160 \rightarrow 200^{\circ} \mathrm{C}$ at $5^{\circ} \mathrm{C} ; 200 \rightarrow 220^{\circ} \mathrm{C}$ at $10^{\circ} \mathrm{C}$; total run time 68 min.; post run $240^{\circ} \mathrm{C}$ for $3 \mathrm{~min}$.

The ion source temperature was adjusted at $230^{\circ} \mathrm{C}$, while the quadrupole temperature was $150^{\circ} \mathrm{C}$. The ionization mode used was electronic impact at 70 electron volt and scanning range $\mathrm{m} / \mathrm{z}$ was $50-650$. The relative percentage of the individual components was calculated from GC/MS peak areas. Identification was performed by comparison of the component mass spectral fragmentation patterns with those stored in the MS database (National Institute of Standards and Technology and Wiley libraries).

\section{RESULTS AND DISCUSSION}

\section{Identification of volatile components in $E$. manipuliflora EOs}

GC/MS technique was used to identify the chemical composition of E. manipuliflora EOs extracted from the plants collected in two periods of growth: before flowering and full flowering. The results demonstrated overall 26 different compounds. Qualitative and quantitative analyses of these EOs is listed in table 1.

Table 1: Chemical composition of Erica manipuliflora essential oils extracted from the aerial parts, as identified by GC/MS technique.

\begin{tabular}{||c|l|c|c||}
\hline Peak No. & \multicolumn{1}{|c|}{ Component } & Before flowering $\%$ & Full flowering\% \\
\hline 1 & $\alpha$-pinene & 0.35 & 0.36 \\
\hline 2 & Camphene & 0.25 & 0.00 \\
\hline 3 & $\beta$-pinene & 3.65 & 18.50 \\
\hline 4 & $\beta$-myrcene & 0.00 & 0.17 \\
\hline 5 & Isoterpinolene & 0.25 & 0.15 \\
\hline 6 & D-limonene & 0.00 & 0.82 \\
\hline 7 & Trans-pinocarveol & 9.25 & 5.58 \\
\hline 8 & Germacrene-D & 35.02 & 16.90 \\
\hline 9 & $\alpha$-terpineol & 5.59 & 2.17 \\
\hline 10 & tau-cadinol & 26.36 & 11.89 \\
\hline 11 & $\beta$-linalool & 0.40 & 0.15 \\
\hline 12 & Isopulegol & 0.28 & 0.00 \\
\hline 13 & Berbenol & 0.72 & 0.16 \\
\hline 14 & Terpinene-4-ol & 1.08 & 0.00 \\
\hline 15 & 2-pinene-4-ol & 0.00 & 0.61 \\
\hline 16 & $\beta$-caryophyllene & 14.78 & 0.00 \\
\hline 17 & Linalool (mono) & 0.00 & 1.20 \\
\hline 18 & $\beta$-phenylethanol & 0.29 & 2.61 \\
\hline 19 & Verbenol & 0.00 & 2.19 \\
\hline 20 & Decanal & 0.95 & 1.75 \\
\hline 21 & $\beta$-citral & 0.00 & 22.26 \\
\hline 22 & Trans-geraniol & 0.00 & 1.27 \\
\hline 23 & $\beta$-bisabolene & 0.00 & 2.15 \\
\hline 24 & Trans-caryophyllene & 0.17 & 7.61 \\
\hline 25 & Tricosane & 0.60 & 0.24 \\
\hline 26 & Heptacosane & 0.00 & 1.26 \\
\hline & & & \\
\hline
\end{tabular}


Table 1 revealed the existence of 26 volatile compounds in E. multipliflora. The major compound was Germacrene-D, which represented 35.02 and $16.90 \%$ in the EOs extracted from aerial parts of this plant in the two growth periods (before flowering and full flowering, respectively). These values were higher than that recorded by Kuş et al. ${ }^{36}$ (14.76 and $15.55 \%$, in aerial parts and flower part, respectively); followed by tau-cadinol (26.36 and $11.89 \%$ respectively in the two growth periods mentioned above). These values were higher than that recorded by Kuş et al. ${ }^{36}$ which were 7.53 and $4.11 \%$ in the aerial parts and flower part, respectively.

The EO extracted from plant collected before flowering period characterized by containing $\beta$-caryophellene $(14.78 \%)$; while this component was absent in the EO extracted from the plant collected in the full flowering period. Besides, the percent of $\beta$-caryophellene were higher than that recorded in other research, which were 7.24 and $5.97 \%$, in aerial parts and flower part, respectively (Kuş et $\left.a l .^{36}\right)$.

The EO of Erica multipliflora collected before flowering period contained high amounts of Trans-pinocarveol, $\alpha$-terpineol, $\beta$ pinene $(9.25,5.59$ and $3.65 \%$, respectively). However, Trans-pinocarveol and $\alpha$-terpineol were higher than that recorded by Kuş et al. ${ }^{36}$ (5.78 and $6.85 \%$, respectively).

$\beta$-citral was the most abundant component in the EO of E. manipuliflora collected in full flowering period, which represented $22.26 \%$ and was absent in the EO extracted from the plant collected before flowering period; followed by $\beta$-pinene, which represented $18 \%$ in the EO extracted from the plant collected in the full flowering period, and only $3.65 \%$ in the EO extracted from the plant collected before flowering period. The other main distinct components in EO of E. manipuliflora collected in full flowering period were Transcaryophellene, Verbenol, $\beta$-bisabolene, which represented $7.61,2.19,2.15 \%$, respectively, and were absent in the EO of E. manipuliflora collected before flowering period. The percent of verbenol was higher than that recorded by Kuş et $a l^{36}$, who found that the verbenol represents $1.17 \%$ in the EO extracted from $E$. manipuliflora flower part.
The differences in the chemical composition between EOs extracted from the plant in the two growth periods (before flowering and full flowering stages) can be illustrated by the fact that Sesquiterpene hydrocarbons are the most abundant compounds in aerial parts of essential oils; while monoterpenoids are found to be most abundant compounds in flower part of essential oil (Kuş et al. ${ }^{36}$ ). So major components of the EO extracted from the plant collected before flowering stage were: Germacrene-D, taucadinol and $\beta$-caryophyllene (35.02, 26.36 and $14.78 \%$, respectively), and all of them are classified as Sesquiterpenes; while the major components in the EO extracted from the plant collected in the full flowering period were $\beta$ citral and $\beta$-penine (22.26 and $18.50 \%$, respectively) and they both classified as monoterpenoids.

\section{Erica manipuliflora EO antibacterial activity}

The essential oils of E. manipuliflora extracted in two growth periods namely: before flowering and full flowering, were tested invitro against 2 gram-positive bacteria (Staphylococcus aureus and Bacillus subtilis), and 2 gram-negative bacteria (Escherichia coli and Salmonella enteritidis), using MBC method. Each EO was prepared in 5 concentrations $\left(2,4,8,16\right.$, and $\left.32 \mathrm{mg} \cdot \mathrm{ml}^{-1}\right)$ by adding the suitable amounts of EO, tween 80 $(0.5 \% \mathrm{~V} / \mathrm{V})$ and $\mathrm{NB}$ to complete the volume to $1 \mathrm{ml}$. Each test was done in triplicates. The values of MBCs are shown in table 2.

Table 2 showed that Gram-positive bacteria were less resistant to E. manipuliflora EOs than Gram-negative bacteria, and this result was in agreement with that of SmithPalmer et $a l^{37}$, who found that Gram-positive bacteria are more sensitive and usually less resistant to the plant-origin antimicrobials, because of the lipopolysaccharide outer membrane of Gram-negative bacteria, which restricts diffusion of hydrophobic compounds, compared to Gram-positive bacteria ${ }^{38 \& 39}$.

Bacillus subtilis was the most sensitive bacterium to E. manipuliflora EOs, with $\mathrm{MBC}$ values equal to 16 and $8 \mathrm{mg} \cdot \mathrm{ml}^{-1}$ in the EOs extracted from the plant before flowering and full flowering periods, respectively. Salmonella enteritidis was the most resistant bacterium to the EOs (MBC values were $32 \mathrm{mg} \cdot \mathrm{ml}^{-1}$ for each of the two EOs). 
Table 2: Minimum bactericidal concentration (MBC) values of EOs extracted from Erica manipuliflora in two growth periods against Gram-positive and Gram-negative bacteria.

\begin{tabular}{|c|c|c|c|c|c|c|c|c|c|c|}
\hline \multirow{3}{*}{ Bacterial strains } & \multicolumn{10}{|c|}{ Concentration of E. manipuliflora EOs (mg.ml $\left.{ }^{-1}\right)$} \\
\hline & \multicolumn{5}{|c|}{ Before flowering } & \multicolumn{5}{|c|}{ Full flowering } \\
\hline & 2 & 4 & 8 & 16 & 32 & 2 & 4 & 8 & 16 & 32 \\
\hline Bacillus subtilis & $+{ }^{*}$ & + & + & $-{ }^{* * *}$ & - & + & + & - & - & - \\
\hline Staphylococcus aereus & + & + & + & - & - & + & + & + & - & - \\
\hline Escherichia coli & + & + & + & + & - & + & + & + & - & - \\
\hline Salmonella enteritidis & + & + & + & + & - & + & + & + & + & - \\
\hline
\end{tabular}

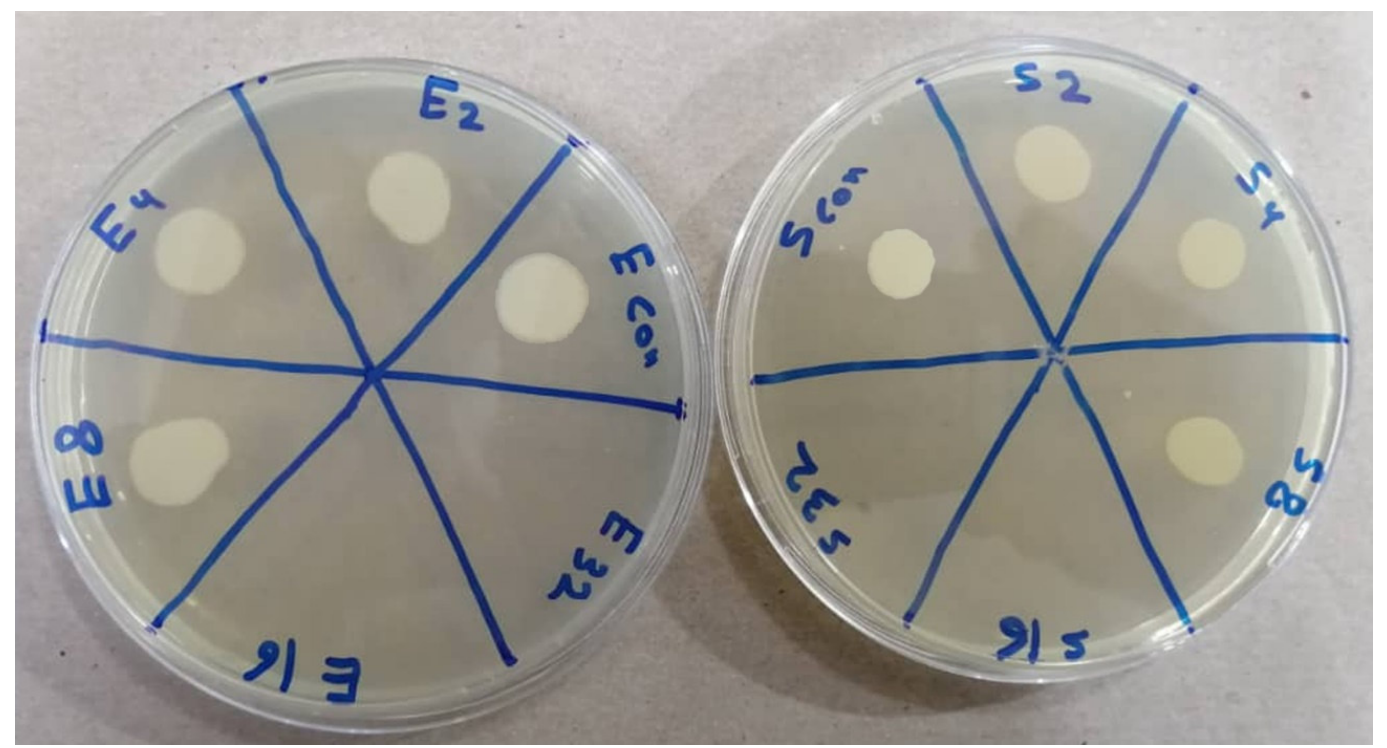

Fig. 1: Antibacterial activity of the EO of Erica manipuliflora collected in full flowering period; from right to left Staphylococcus aureus and Escherichia coli.

According to our knowledge there are not any study in the literatures about the antimicrobial activity of the EOs extracted from E. manipuliflora against $B$. subtilis, S.aureus, E. coli and S. enteritidis, although literatures studied the antimicrobial activity of EOs extracted from other species of the genus Erica, or the antimicrobial activity of solvent extracts of E. manipuliflora ${ }^{10,14 \& 15}$. So this is the first study about the antibacterial activity of E. manipuliflora EOs against these four bacterial species.

The EO of E. manipuliflora collected in full flowering period was more active against some studied species namely: $B$. subtilis and $E$. coli than EO extracted from the same plant collected before flowering period (Fig. 1). This result may be due the presence of some active components in the EO extracted from the plant in full flowering period such as $\beta$-citral, transgeraniol, which are active against $S$. aureus, $E$. coli, and S. enteritidis subsp. Typhimurium ${ }^{40}$.

\section{Conclusion}

Erica manipuliflora is a wild plant native to Mediterranean regions, including Syria. However, the composition of the essential oil of this plant are not investigated in Syria, and rare researches have been conducted about this EO around the world. Moreover, the antimicrobial activity of E. manipuliflora EO against bacteria is not evaluated. Results revealed differences between the EOs extracted from E. manipuliflora before flowering and in full flowering periods. The antibacterial study showed that these EO had a moderate activity 
against some pathogenic bacteria, with minimum bactericidal concentration (MBC) values ranged from 8 to $32 \mathrm{mg} \cdot \mathrm{ml}^{-1}$. Also results revealed the differences in the EOs extracted from plant before flowering and in full flowering periods. We suggest studying the composition of volatile components of other species of the genus Erica native to Syria, and investigating the antimicrobial activity of these essential oils against other pathogenic bacteria.

\section{REFERENCES}

1- L. A. Shelef, "Antimicrobial effects of spices", J. Food Safety, 6, 29-44 (1983).

2- L. L. Zaika, "Spices and herbs: Their antimicrobial activity and its determination", J. Food Safety, 9, 97-118 (1988).

3- J. Newman and G. M. Cragg, "Natural products as sources of new drugs over the 30 years from 1981 to 2010", J. Nat. Prod., 75 (3), 311-335 (2012).

4- I. Parejo, F. Viladomat, J. Bastida, A. Rosas- Romero, G. Saavedra, M. A. Murcia, A. M. Jimenez and C. Codina, "Investigation of Bolivian plant extracts for their radical scavenging activity and antioxidant activity", Life Sci., 73,16671681 (2003).

5- A. Lhuillier, "Contribution à L'étude Phytochimique de Quatre Plantes Malgaches: Agauria sallicifolia Hook. F. Ex Olivier, Agauria polyphylla Baker (Ericaceae), Tambourissa trichophylla Baker (Mininiaceae) et Embelia concinna Baker (Myrsinaceae)", Thèse de Doctorat de L'institut National Polytechnique de Toulouse, 2007, p. 200.

6- J. Bruneton, "Plantes Toxiques: Végétaux Dangereux pour l'Homme et les Animaux", $1^{\text {st }}$ Edn., Paris, Editions Techniques et Documentation Lavoisier, 2001, pp. 241-242.

7- B. Márquez-García, M. A. Fernández and F. Córdoba, "Phenolics composition in Erica sp. differentially exposed to metal pollution in the Iberian Southwestern pyritic belt", Bioresour. Technol., 100, 446-451 (2009).

8- V. D. Mitic, M. D. Ilic, V. P. StankovJovanovic, G. S. Stojanovic and M. V. Dimitrijevic, "Essential oil composition of
Erica spiculifolia Salisb-first report", Nat. Prod Res., 32 (2), 222-224 (2018).

9- P. Dias, A. Martins A. C. Figueiredo and A. P. Rauter, "Flower Colour and Essential oil composition in Erica australis L. Grown in Portugal", J. Essent. Oil Bear Pl., 19 (4), 1013-1018 (2016).

10- E. K. Akkol, E. Yeşilada and A. Güvenç, "Valuation of anti-inflammatory and antinociceptive activities of Erica species native to Turkey", J. Ethnopharmacol., 116 (2), 251-257 (2008).

11- E. G. H. Oliver, "Systematics of Ericeae (Ericaceae: Ericoideae) species with indehiscent and partially dehiscent fruits", Contrib. Bolus Herb., 9, 1-483 (2000).

12- C. Sadki, B. Hacht, A. Souliman, and F. Atmani, "Acute diuretic activity of aqueous Erica multiflora flowers and Cynodon dactylon rhizomes extracts in rats", J. Ethnopharmacol., 128 (2), 352356 (2010).

13- R. M. Reyes, C. Martin-Cordero, M. J. Ayuso Gonzalez, M. V. Toro Sainz, and C. Alarcon de la Lastra, "Antiulcer activity in rats by flavonoids of Erica andevalensis Cabezudo-Rivera", Phytother. Res., 10 (4), 300-303 (1996).

14- A. Santos, Â. Luís, S. Ferreira and A. P. Duarte, "Antioxidant and antimicrobial activity and potential of heather (Erica spp.) extracts in the control of Listeria monocytogenes", Int. J. Food Sci. Tech., 54 (3), 862-870 (2018).

15- N. Guendouze-Bouchefa, K. Madani, M. Chibane, L. Boulekbache-Makhlouf, D. Hauchard, M. Kiendrebeogo, C. Stevigny, P. N. Okusa and P. Duez, "Phenolic compounds, antioxidant and antibacterial activities of three Ericaceae from Algeria", Ind. Crops. Prod., 70, 459-466 (2015).

16- V. Veličković, S. Đurović, M. Radojković, A. Cvetanović, J. Švarc-Gajić, J. Vujić, S. Trifunović and P. Z. Mašković, "Application of conventional and nonconventional extraction approaches for extraction of Erica carnea L.: Chemical profile and biological activity of obtained extracts", J. Supercrit Fluid., 128, 331337 (2017).

17- R. Nunes, S. Rodrigues, P. Pasko, M. Tyszka-Czochara, A. Grenha and I. 
Saraiva de Carvalho, "Effect of Erica australis extract on Caco-2 cells, fibroblasts and selected pathogenic bacteria responsible for wound infection", Ind. Crops Prod., 52, 99-104 (2014).

18- Ö. Ertürk, "Antibacterial and antifungal activity of ethanolic extracts from eleven spice plants", Biologia., 61 (3), 275-278 (2006).

19- B. Şen, S. Kessler, B. Gurdal, A. Kiemer and A. Mat, "The difference between the extracts of Erica manipuliflora in flowering and fruiting periods in terms of the cytotoxic effects", J. Fac Pharm., 46 (2), 71-78 (2016).

20- R. D. Pavlović, B. Lakusićć, Z. DoslovKokorus and N. Kovacević, "Arbutin content and antioxidant activity of some Ericaceae species", Pharmazie, 64 (10), 656-659 (2009).

21- B. Márquez-García and F. Córdoba, "Antioxidative system in wild populations of Erica andevalensis", Environ. Exp. Bot., 68 (1), 58-65 (2010).

22- B. Márquez-García, N. Horemans, A. Cuypers, Y. Guisez and F. Córdoba, "Antioxidants in Erica andevalensis: A comparative study between wild plants and cadmium-exposed plants under controlled conditions", Plant Physiol. Bioch., 49 (1), 110-115 (2011).

23- B. Márquez-García, M. FernándezRecamales and F. Córdoba, "Effects of cadmium on phenolic composition and antioxidant activities of Erica andevalensis", J. Botany, 2012, Article ID 936950, (2012).

24- I. Nogués, J. Peñuelas, J. Llusià, M. Estiarte, S. Munné-Bosch, J. Sardans and F. Loreto, "Physiological and antioxidant responses of Erica multiflora to drought and warming through different seasons", Plant Ecol., 213 (4), 649-661,(2012).

25- H. Nazemiyeh, F. Bahadori, A. Delazar, M. Ay, G. Topçu, U. Kolak, L. Nahar, A. A. Auzie and S. D. Sarker, " Tricetin 4'-O$\alpha$-L-rhamnopyranoside: A new flavonoid from the aerial parts of Erica arborea", Chem. Nat. Compd., 44 (2), Article No. 174 (2008).

26- C. Martin-Cordero, M. Reyes, M. J. Ayuso and V. Toro, "Cytotoxic triterpenoids from Erica andevalensis", $\boldsymbol{Z}$. Naturforsch. C, 56 (1-2), 45-48 (2001).

27- A. Ballester, A. Verwey and J. C. Ovbreem, "2-Hydroxyphenylacetic acid and 2, 4-dihydroxyphenyl acetonitrile from Erica scoparia", Phytochem., 14 (7), 1667-1668 (1975).

28- B. Bennini, A.J. Chulia, M. Kaouadji and C. Delage, "(2R,3R)-Dihydroflavonol aglycone and glycosides from Erica cinerea", Phytochem., 33 (5), 1233-1236 (1993).

29- A. J. Chulia, B. Benini, M. Kaouadji, D. P. Allais, and C. Delage, "Two flavonol conjugates from Erica cinerea", J. Nat. Prod., 58 (4), 560-563 (1995).

30- R. K. Crowden and J. R. Jarman, "Anthocyanins in the genus Erica", Phytochem., 15 (11), 1796-1797 (1976).

31- J. Méndez, "Isofraxidin in Erica flowers", Phytochem., 17 (4), 820 (1978).

32- E. Vieitez and A. Ballester, "Phenolic and coumaric components in Erica cinerea", Anales. Inst Bot. Cavanilles., 29, 129-142 (1972).

33- F. G. Kırbaşlar, A. Tavman, B. Dülger, and G. Türker, "Antimicrobial activity of Turkish citrus peel oils", Pak. J. Bot., 41 (6), 3207-3212 (2009).

34- H. Boudries, S. Loupassaki, Y. Ladjal Ettoumi, S. Souagui, M. Bachir Bey, N. Nabet, A. Chikhoune, K. Madani and M. Chibane, "Chemical profile, antimicrobial and antioxidant activities of Citrus reticulata and Citrus clementina (L.) essential oils", International Food Research Journal, 24 (4), 1782-1792 (2017).

35- A. Sheeladevi and N. Ramanathan, "Antibacterial activity of plant essential oils against food borne bacteria", International Journal of Pharmaceutical \& Biological Archives., 3 (5), 1106-1109 (2012).

36- C. Kuş, M. Taş, S. Küçükaydın, G. TelÇayan, and M. E. Duru, "Chemical analysis and in-vitro antioxidant and anticholinesterase activities of essential oils and extracts from different parts of Erica manipuliflora", J. Res. Pharm., 23 (6), 1098-1105 (2019).

37- A. Smith-Palmer, J. Stewart, and L. Fyfe, "The potential application of plant 
essential oils as natural food preservatives in soft cheese". Food Microbiology, 18, 463-470 (2001).

38- M. E. A. Stefanello, A. C. Cervi, I. Y. Ito, M. J. Salvador, A. J. Wisniewski and E. L. Simionatto, "Chemical composition and antimicrobial activity of essential oils of Eugenia chlorophylla (Myrtaceae) ", Journal of Essential Oil Research, 20, 75-78 (2008).

39- K. B. Rameshkumar, V. George and S. Shiburaj, "Chemical constituents and antibacterial activity of the leaf oil of
Cinnamomum chemungianum Mohan et Henry", Journal of Essential Oil Research, 19, 98-100 (2007).

40- A. C. Guimarães, L. M. Meireles, M. F. Lemos, M. C. C. Guimarães, D. C. Endringer, M. Fronza and R. Scherer, "Antibacterial activity of terpenes and terpenoids present in essential oils", Molecules, 24, 2471 (2019). 


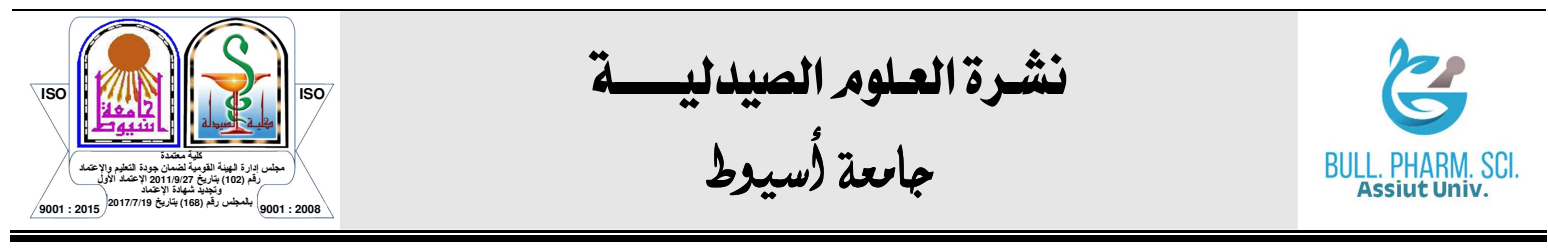

\section{الفعالية المضادة للبكتريا في الزجاج و التركيب الكيميائي للزيت العطري لنبات

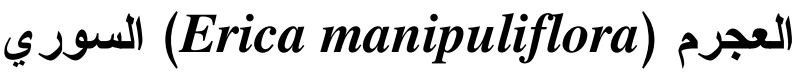

'ميس طلال طلاس' - عصام الثماع' - جلال فندي' - عماد الحداد'

$$
\text { ' ق قسم العقاقير ، كلية الصيدلة ، جامعة دمشق ، دمشق ، سوريا }
$$

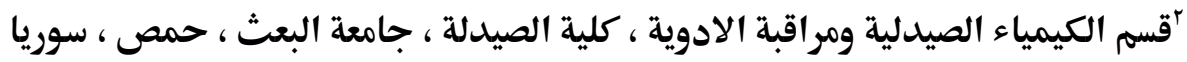

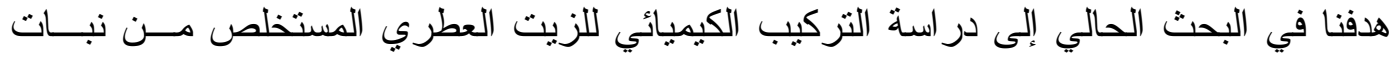

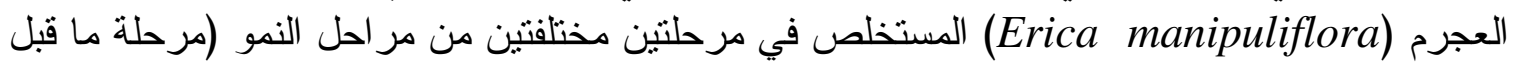

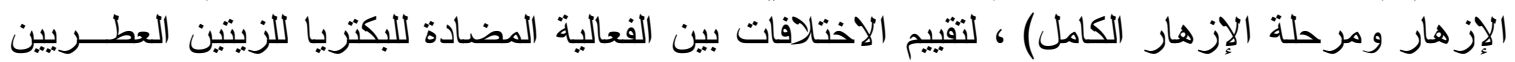

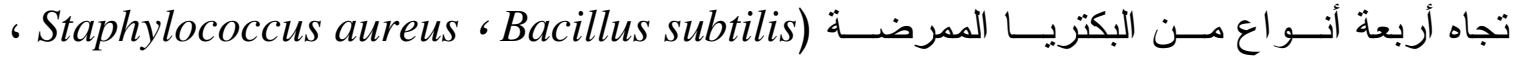
في Escherichia coli

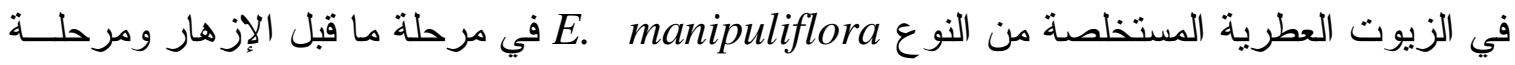

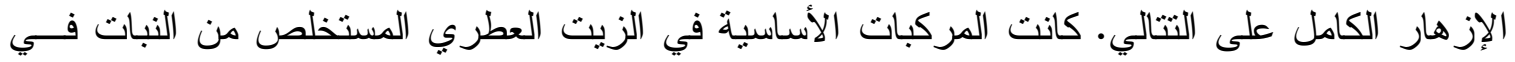

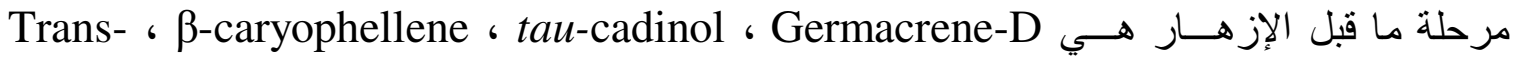
terpinocarveol

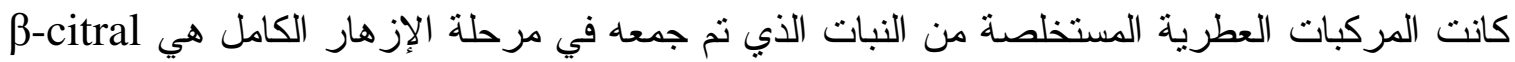
، trans-terpinocarveol g tau-cadinol ، Germacrene-D ، $\beta$-pinene ،

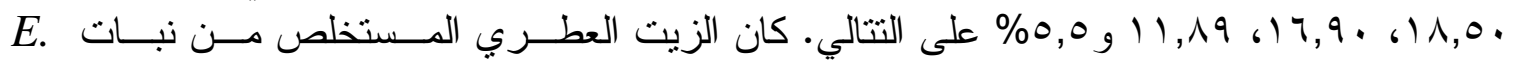
manipuliflora

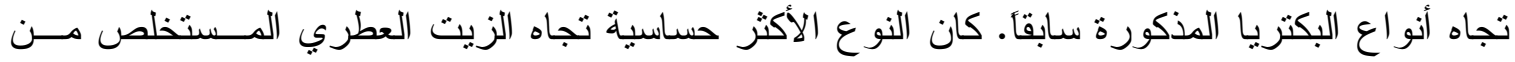

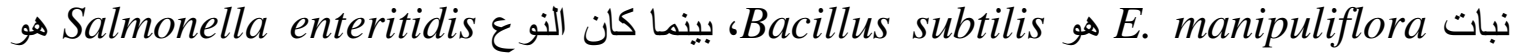

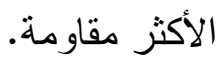

